\title{
1. Introduction to the Research Handbook on Transnational Crime
}

\author{
Valsamis Mitsilegas, Saskia Hufnagel and Anton Moiseienko
}

In an increasingly mobile and interconnected world, transnational crime - that is, crime that directly affects more than one country - is more prevalent than ever before. Various forms of illicit trafficking have become easier to conceal amidst vast flows of goods and people. Terrorist groups attract recruits from overseas by broadcasting propaganda. Terrorists and other criminals move funds across the world more easily. The emergence of the internet has facilitated the commission of cross-border crime and given rise to cybercrime, which often involves stealing from a victim in a developing country and transferring the proceeds into other jurisdictions.

Against this background, transnational crime has become increasingly difficult to study, let alone counteract. A scholar of transnational crime is faced with a bewildering array of criminal behaviour, criminal actors, methodological perspectives and geographical locations to consider. Given its sheer diversity, the whole utility of thinking about transnational crime as a field of enquiry may appear questionable. Yet by focusing too closely on specialist areas of concern one risks missing the proverbial wood for the trees - that is, factors common to various strands of transnational crime and the shared challenges of addressing it.

The objective of this Handbook is to serve as a guide for the exploration of transnational crime. It aims to both elucidate common trends in relation to transnational crime and do justice to specific types of crime and geographical regions. It covers a number of major types of transnational crime, including terrorism, money laundering, environmental crime, migration-related crime, human trafficking, drug trafficking, cybercrime and heritage crime.

Each of these areas of transnational criminal activity is addressed in three separate contributions covering legal perspectives, criminological perspectives, and policing and prosecution of the relevant type of crime. Ordering contributions in this manner ensures that they can either be read in isolation or as three-part sections providing a well-rounded overview of the relevant issues. The aim of this structure is to emphasise the added value of a cross-disciplinary and multi-level approach to the study of transnational criminality.

To highlight the recurring and transversal challenges posed by transnational crime and its study, this Handbook opens with a set of three contributions examining transnational crime as a whole. They follow a tripartite division into legal, criminological, and policing and prosecution aspects, which runs consistently throughout the whole book. These chapters set the stage for the following discussion of, first, specific types of transnational crime and, second, geographical regions of interest.

The first theme relates to applicable legal standards. As states have acknowledged a shared interest in combating various forms of transnational crime, they have resorted to rule-making at the international level, either in the form of binding international treaties, such as the UN Convention on Transnational Organized Crime or soft law, such as 40 Recommendations by the Financial Action Task Force. Chapters on legal perspectives consider the relationship 
between 'hard' and 'soft' law in the development of such rules, their content and the challenges to their adoption or enforcement, with some contributions focusing on the issues of domestic implementation in a given jurisdiction.

As is well known, however, one can seldom legislate one's jurisdiction out of a problem. The book is therefore not limited to black-letter law. The chapters on criminological perspectives provide a glimpse into the non-legal, human and social dimensions of transnational crime. For the most part, they explore who commits it, how it is perpetrated and what approaches can be taken to its prevention or investigation. Some chapters, however, take a critical stance and either highlight the adverse impact that criminal justice policies have on different parties to the criminal process, such as victims, or question the need for criminalisation in the first place. These, for instance, are the topics of the chapters on criminological perspectives on migration crime and drug trafficking respectively. The study of the effects of criminal justice policies is essential to understanding how theoretical insights and legal provisions correspond to experiences on the ground.

A better understanding of transnational crime sets the stage for a discussion of its policing and prosecution, which is the third theme running through the book. It is here that the differences to other crimes are arguably at their most salient. While transnational crime by definition crosses borders, law enforcement powers are territorial and international collaboration can be cumbersome. As an old adage goes, 'if borders did not exist, criminals would have to invent them'. Discussing how policing and prosecution function in the context of transnational crime is indispensable to any serious examination of the subject. It is arguable that the challenges of cross-border cooperation, which are common to some extent to various types of transnational crime, are a major reason for thinking about transnational crime as a coherent concept rather than a set of distinct problems. The chapters on enforcement also bridge the gap between the law in the books and the law in practice. While legislation exists in the field of transnational crime, the enforcement is extremely challenging. These challenges are first addressed in a general chapter on international law enforcement in the area of transnational crime, but then much more specifically addressed within the crime types. This is particularly important as the policing and prosecution challenges are significantly different depending on the crimes and their main geopolitical origin, transit and destination areas.

Regional perspectives on transnational crime are covered in the six final chapters of the book. Their inclusion is an acknowledgement of the fact that, although transnational crime is an inherently international business, some geographical locales are more susceptible to its impact than others. Like unhappy families that are all unhappy in their own way, each of the regions considered in the book has its own peculiar characteristics that are conducive to transnational crime.

In the EU, these are the open borders within the Schengen area and the free movement of goods, people and capital. (One could argue, however, that EU member states' access to pan-European criminal mechanisms such as Europol, Eurojust and the European Arrest Warrant mitigate the effects of open borders - a proposition that may or may not be tested by the UK's planned departure from the EU.) These supranational EU policing and prosecution issues are first discussed in the more general policing and prosecution chapter, as the EU is the only region in the world with detailed cross-border regulation facilitating police and judicial cooperation in the fight against transnational crime. It is then again discussed in the chapter on the Meuse-Rhine Euroregion, where Belgium, Germany and the Netherlands meet, which acts as a microcosm of the region, in which the criminal justice challenges brought about by 
the EU's ever greater integration play out. In Asia, by contrast, it is corruption and economic inequality that are the main driving forces behind transnational crime.

Like the Meuse-Rhine Euroregion, South America boasts its own Tri-Border Area, the one allegedly beloved by drug traffickers and other criminals, including overseas outposts of Hezbollah. As one of the chapters highlights, the perennial weakness of South American state institutions in controlling borders partly accounts for the transnational crime issues the region experiences. This is compounded by corruption, an issue that is also felt acutely in both the ex-Soviet Union countries and the African Union, two of the other regions covered in the Handbook. Although the manifestations of corruption differ in these two parts of the world, with ex-Soviet countries carving out a role for themselves as centres of fraud and cybercrime while Africa is particularly notable for the scale of its human trafficking, the role of corruption as a cross-cutting criminal enabler is beyond doubt particularly prominent; it is perhaps the one common feature that is present in the transnational crime landscape across continents. As a consequence of government bureaucracies being afflicted by corruption, both in the former Soviet Union and in Africa, much of the activity directed against transnational crime is liable to be seen as mere window-dressing.

At the same time, the prevalence of transnational crime cannot be explained solely by governance failures, given the range of challenges that cross-border criminality poses for even well-equipped criminal justice systems. As a starting point for tackling those, transnational crime needs to be understood and studied, and it is hoped that this Handbook will be of some assistance to those who do so. 